\title{
GHG intensities from the life cycle of conventional fuel and biofuels
}

\author{
H. H. Khoo ${ }^{1}$, R. B. H. $\operatorname{Tan}^{2}$ \& Z. $\operatorname{Tan}^{2}$ \\ ${ }^{1}$ Institute of Chemical and Engineering Sciences, Singapore \\ ${ }^{2}$ Department of Chemical and Biomolecular Engineering, \\ National University of Singapore, Singapore
}

\begin{abstract}
Among all the various air pollution issues, greenhouse gases are the key environmental and global concern that the world is facing today. The European Union's project on Carbon Measurement Toolkit was developed to determine the greenhouse gas (GHG) intensities of products. This kind of evaluation is important for fast growing industrial nations, especially in assessing sources of alternative energy. Life cycle assessment or LCA is used to model the following fuels delivered to Singapore: foreign conventional fuel production; biofuels from palm oil grown in neighbouring countries (with 'worst' and 'best' cases of direct land use change); and biodiesel produced from used cooking oil in Thailand. The life cycle approach used in this article is similar to the method developed by the European Union's Carbon Measurement Toolkit. The case studies involve raw material production/plantation, processing and final delivery by long-distance transportation. The investigation highlights that despite being labelled as a "green" or "carbon neutral" source of renewable energy, the actual ability of biofuels (especially those made from crops) to reduce GHGs hangs delicately on several crucial factors, namely, direct land use change.
\end{abstract}

Keywords: greenhouse gases, life cycle assessment (LCA), biofuels, cradle-topump, Carbon Measurement Toolkit, direct land use change (LUC).

\section{Introduction}

Due to the depletion of fossil fuels, the use of biofuels as a renewable source of energy has gained worldwide attention. The focus on these 'green' energy carriers has accelerated along with the need to mitigate global warming. 
However, long-term plans or strategies to replace biofuels with conventional ones should be implemented with caution. The authors assert that biomass-tobioenergy production systems are not without social and ecological risks since all fuel production industries require resource extraction and energy inputs [1].

Biofuels cannot be considered a sustainable solution to energy security if their production results in environmental destruction, deforestation, or food shortage $[2,3]$. The "Carbon Footprint" of a product is generally the sum of carbon dioxide $\left(\mathrm{CO}_{2}\right)$ and other greenhouse gases - carbon monoxide $(\mathrm{CO})$, methane $\left(\mathrm{CH}_{4}\right)$, and nitrous oxide $\left(\mathrm{N}_{2} \mathrm{O}\right)$ - generated throughout the life cycle of a product. The European Union's Carbon Measurement Toolkit [4] was developed to calculate the total GHGs of products, taking into account all the phases of the life cycle (fig. 1).

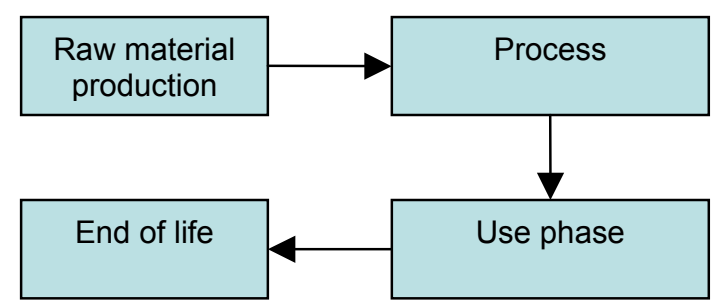

$G H G=E A 1^{*} \mathrm{a} 1+E A 2^{*} \mathrm{a} 2+\ldots E A n^{*} \mathrm{an}$

Where:

- GHG is the total emission of greenhouse gases expressed in mass of $\mathrm{CO}_{2}$ equivalent or $\mathrm{CO}_{2}$-eq

- $E A \boldsymbol{i}$ are the values of the environmental aspects provided by the applicant

- $\quad a i$ are the conversion factors that will be provided in the tool after this project

Figure 1: $\quad$ Life cycle diagram of toolkit [4].

\section{Production of conventional fuel and biofuels}

Based on the Carbon Measurement Toolkit concept, the following life cycle stages of fuels delivered to Singapore are modeled:

1) foreign conventional fuel production, which is locally refined into petro-diesel

2) biodiesel from palm oil with 'best' reported case of land use

3) biodiesel from palm oil with 'worst' reported case of land use

4) biodiesel produced from used cooking oil in Thailand.

The life cycle system boundary is from 'cradle-to-pump'. The cradle starts with crude oil mining for case 1, biomass plantation for cases 2 and 3, and used cooking oil collection for case 4 . The life cycle ends at the pump, which is selected as $1 \mathrm{MJ}$ diesel/biodiesel ready for use. 


\subsection{Conventional fuel production (case 1)}

Conventional fuel production is a matured industry and several reports describing its operations are widely available. The first life cycle stages of conventional fuel is foreign crude oil extraction and separation, next, storage and handling before it is shipped by ocean tanker to a refinery in Singapore (fig. 2). Fossil fuel inputs of oil and natural gas is required in the process [5]. Electrical energy is used for pumping and transferring crude oil out of wells, and injecting excess water back in. Compared to shipment distance from Middle East to Singapore $(8,000 \mathrm{~km})$, the emissions from local transportations for oil production, separation or storage/handling operations are considered minimal. At the refinery, the hydrocarbon chains are separated by fractional distillation at about $200^{\circ} \mathrm{C}$ and $350^{\circ} \mathrm{C}$, followed by hydrocracking to produce petro-diesel.

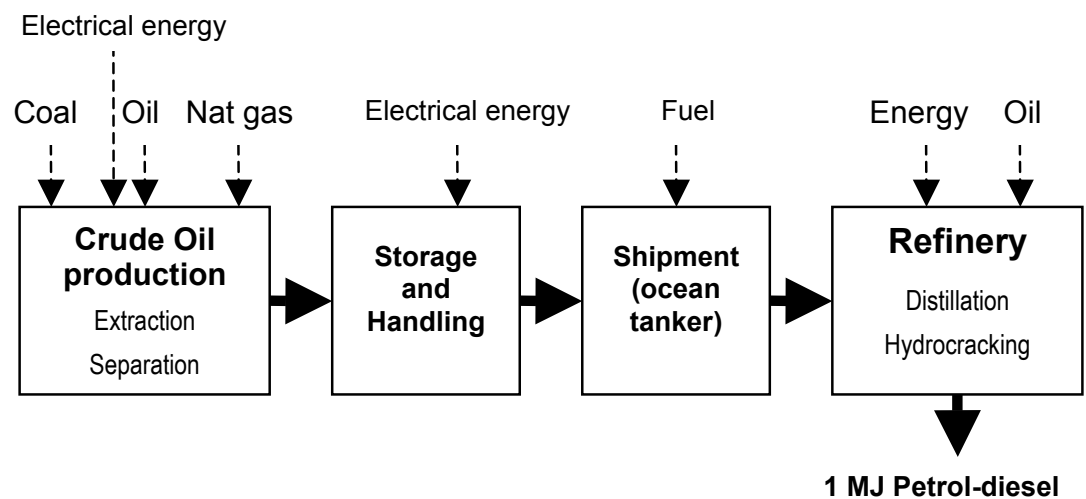

Figure 2: Life cycle of foreign fuel production.

The diesel yield from crude oil is taken to be $20 \%$. It is also assumed that no losses occur during crude oil handling, storage and shipment. The energy value of the final diesel product is $42.9 \mathrm{MJ} / \mathrm{kg}$ [5].

\subsection{Biofuel from palm oil (cases 2 and 3)}

Biodiesel is a form of biofuel which can be used to replace petro-diesel for a wide range of applications, including transportation and high-temperature industrial processes. For the case study, biodiesel produced from palm oil grown from a neighbouring country is considered. Several reports have described the processes involved in the production of palm oil $[6,7]$. The life cycle stages start with plantation, harvesting of fresh fruit bunches (FFB), milling of FFB to produce crude palm oil (CPO), which is sent to the biorefinery (fig. 3).

Inputs of fertilizers, fuel, and electrical energy are required in palm oil cultivation and harvesting. The FFB yield is reported to be $18,870 \mathrm{~kg}$ per hectare $(\mathrm{kg} / \mathrm{ha})$ based on a reference year (2007); and $0.2 \mathrm{~kg}$ CPO can be derived from $1 \mathrm{~kg}$ FFB [8]. At the biorefinery, $95 \%$ of CPO is processed into refined, bleached and deodorized (RDB) oil and finally, 100\% RDF is converted to biodiesel. The 
final biodiesel has a value of $37.9 \mathrm{MJ} / \mathrm{kg}$ [9]. Sequestration of $\mathrm{CO}_{2}$ occurs via photosynthesis during the growth of palm oil trees.

This article attempts to highlight the important fact that despite being labeled as 'green' or 'carbon neutral' fuels, the actual ability of biofuels (made from crops) to reduce greenhouse gases hangs delicately on several crucial factors, namely direct land use change [1-3]. Environmental scientists have been critical over biofuels made from palm oil primarily due the clearing of forestland and loss of biodiversity $[3,10,11]$.

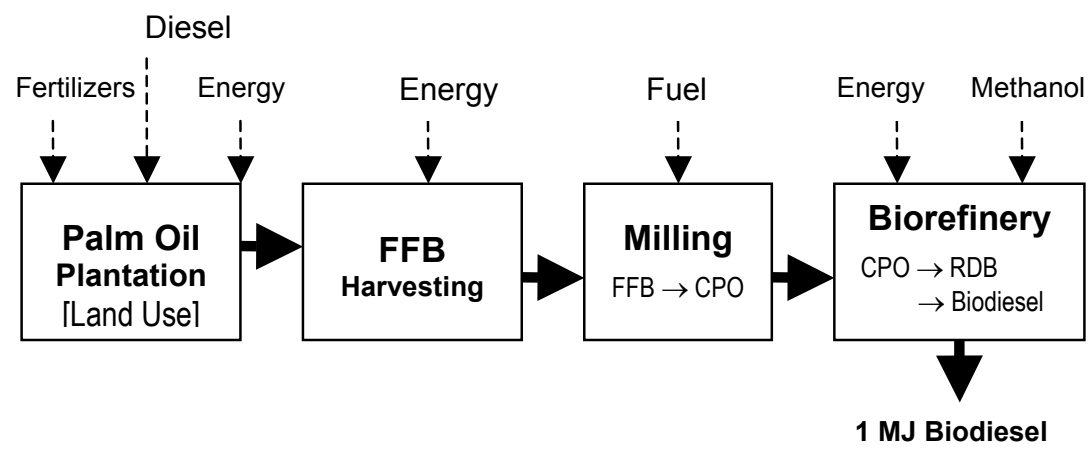

Figure 3: Life cycle of palm oil to biodiesel.

\subsection{Biodiesel production from used cooking oil in Thailand (case 4)}

The fourth case study is from Thailand, where used cooking oil (UCO) is collected and converted into biodiesel via a process known as transesterification (fig. 4). The process is semi-continuous, with a maximum operating capacity of 3 batches per day [12]. The production output is reported to be 1000 litres per batch.

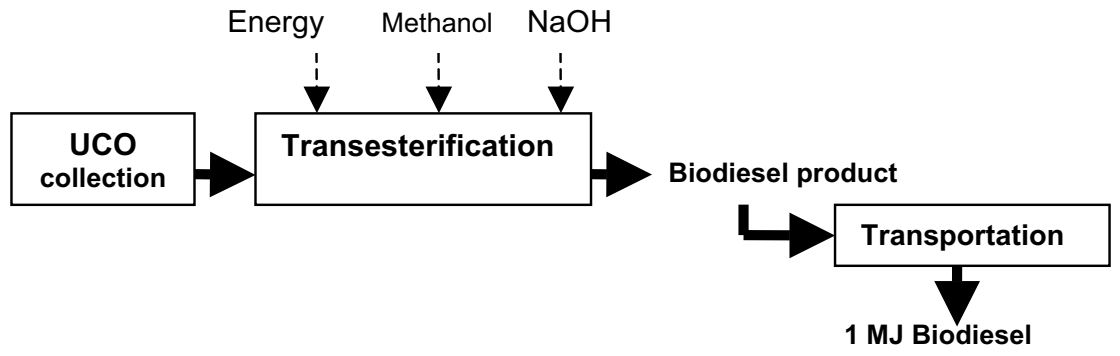

Figure 4: $\quad$ Life cycle of UCO to biodiesel.

The reactants for the process are methanol (mainly) and sodium hydroxide or $\mathrm{NaOH}$ as catalysts. Energy requirements are supplied as electrical power from the Thai national electricity grid [12]. The energy content of the biodiesel is expected to be $42.65 \mathrm{MJ} / \mathrm{kg}$ [13]. 


\section{GHG emission data and calculations}

\subsection{Greenhouse gas emission data}

The data for the case studies are obtained from personal communication with companies and institutes involved in palm oil biodiesel research, and supplemented by several reports $[5,7-9,12]$. They are compiled in Tables 1,2 and 3 . In case studies 2 and 3, fertilizer inputs are required during the plantation stage.

Table 1: Inputs and associated GHG for conventional petro-diesel production.

\begin{tabular}{|c|c|c|c|c|}
\hline \multicolumn{5}{|c|}{ CASE 1: Conventional production of $1 \mathrm{MJ}$ petro-diesel } \\
\hline Life cycle stages & \multicolumn{2}{|c|}{ Resource input (R) } & \multicolumn{2}{|c|}{ Energy input (E) } \\
\hline \multirow{3}{*}{$\begin{array}{l}\text { Oil Extraction } \\
\text { (output: crude } \\
\text { oil) }\end{array}$} & Input (kg) & $\begin{array}{c}\mathrm{g} \mathrm{CO}_{2} \text {-eq per } \mathrm{kg} \\
\text { input }\end{array}$ & Type of energy & $\begin{array}{c}\mathrm{g} \mathrm{CO}_{2} \text {-eq per } \\
\mathrm{kWh} / \mathrm{MJ}\end{array}$ \\
\hline & Oil $(0.0811)$ & 256.83 & \multirow{2}{*}{$\begin{array}{l}\text { Electrical energy } \\
(0.012 \mathrm{kWh})\end{array}$} & \multirow[t]{2}{*}{$970^{\mathrm{a}}$} \\
\hline & $\begin{array}{c}\text { Natural gas } \\
(0.00051)\end{array}$ & 512.20 & & \\
\hline $\begin{array}{l}\text { Storage and } \\
\text { Handling }\end{array}$ & - & - & $\begin{array}{l}\text { Electrical energy } \\
\left(2.33 \times 10^{-6} \mathrm{kWh}\right)\end{array}$ & $970^{\mathrm{a}}$ \\
\hline $\begin{array}{c}\text { Refinery } \\
\text { (output: petro- } \\
\text { diesel) } \\
\end{array}$ & $\begin{array}{l}\text { Heavy oil } \\
(0.000256)\end{array}$ & 947.76 & $\begin{array}{l}\text { Electrical energy } \\
(0.0473 \mathrm{kWh})\end{array}$ & $460^{\mathrm{b}}$ \\
\hline Transportation & \multicolumn{4}{|c|}{ Total $2.2 \mathrm{~g} \mathrm{CO}_{2}$-eq for $8,000 \mathrm{~km}$ by ocean tanker } \\
\hline
\end{tabular}

${ }^{\mathrm{a}}$ Coal-fired electricity. $\quad{ }^{\mathrm{b}}$ Singapore electrical grid mix.

Table 2: $\quad$ Inputs and associated GHG for palm oil to biodiesel production.

\begin{tabular}{|c|c|c|c|c|}
\hline \multicolumn{5}{|c|}{ CASE 2/3: The production of $1 \mathrm{MJ}$ biodiesel from palm oil } \\
\hline Life cycle stages & \multicolumn{2}{|c|}{ Resource input (R) } & \multicolumn{2}{|c|}{ Energy input (E) } \\
\hline \multirow{3}{*}{$\begin{array}{c}\text { Palm oil } \\
\text { plantation } \\
\text { (output: FFB) }\end{array}$} & Input $(\mathrm{kg})$ & $\begin{array}{c}\mathrm{g} \mathrm{CO}_{2} \text {-eq per kg } \\
\text { input }\end{array}$ & Type of energy & $\begin{array}{c}\mathrm{g} \mathrm{CO}_{2} \text {-eq per } \\
\mathrm{kWh} / \mathrm{MJ}\end{array}$ \\
\hline & \multirow{2}{*}{$\begin{array}{l}\text { Fertilizer } \\
(0.000224)\end{array}$} & \multirow{2}{*}{205.5} & $\begin{array}{c}\text { Diesel } \\
(0.0153 \mathrm{MJ}) \\
\end{array}$ & 0.0096 \\
\hline & & & $\begin{array}{c}\text { Electricity } \\
(0.00273 \mathrm{kWh})\end{array}$ & $540^{c}$ \\
\hline $\begin{array}{c}\text { Milling } \\
\text { (output: CPO) }\end{array}$ & - & - & $\begin{array}{c}\text { Diesel } \\
(0.205 \mathrm{MJ})\end{array}$ & 0.0096 \\
\hline $\begin{array}{l}\text { Biorefinery } \\
\text { (output: } \\
\text { biodiesel) }\end{array}$ & $\begin{array}{l}\text { Methanol } \\
(0.00260 \mathrm{~kg})\end{array}$ & 786 & $\begin{array}{c}\text { Electricity } \\
(0.00091 \mathrm{kWh})\end{array}$ & $540^{\mathrm{c}}$ \\
\hline
\end{tabular}

${ }^{\mathrm{c}}$ Malaysian electricity grid mix. 
Table 3: $\quad$ Inputs and associated GHG for UCO to biodiesel production.

\begin{tabular}{|c|c|c|c|c|}
\hline \multicolumn{5}{|c|}{ CASE 4: The production of $1 \mathrm{MJ}$ biodiesel from used cooking oil (UCO) } \\
\hline Life cycle stages & \multicolumn{2}{|c|}{ Resource input (R) } & \multicolumn{2}{|c|}{ Energy input (E) } \\
\hline \multirow[t]{2}{*}{ UCO collection } & Input $(\mathrm{kg})$ & $\begin{array}{l}\mathrm{g} \mathrm{CO}_{2} \text {-eq per } \\
\mathrm{kg} \text { input }\end{array}$ & Type of energy & $\begin{array}{l}\mathrm{g} \mathrm{CO}_{2} \text {-eq per } \\
\mathrm{kWh}\end{array}$ \\
\hline & - & - & - & - \\
\hline \multirow[b]{2}{*}{ Transesterification } & Methanol (0.005) & 260 & \multirow{2}{*}{$\begin{array}{l}\text { Electrical energy } \\
(0.000703 \mathrm{kWh})\end{array}$} & \multirow[b]{2}{*}{$740^{\mathrm{d}}$} \\
\hline & $\begin{array}{c}\mathrm{NaOH} \\
(0.00023) \\
\end{array}$ & 1180 & & \\
\hline Transportation & \multicolumn{4}{|c|}{ Total $0.023 \mathrm{~g} \mathrm{CO}_{2}$-eq for $1,275 \mathrm{~km}$ by coastal tanker } \\
\hline
\end{tabular}

${ }^{\mathrm{d}}$ Thai electricity grid mix.

\subsection{Total GHG calculations}

For each $\mathrm{GHG}$ calculation, the $\mathrm{CO}_{2}$-equivalent conversion factors for global warming are made in accordance with the IPCC Third Assessment Report, Climate Change 2001. For all cases, the calculations for GHG intensities for the processing stages, from cradle-to-gate, are as follows:

$$
\sum G H G=\sum_{p} \sum_{i}\left(R_{p, i} * C O_{2} e q 1_{i}\right)+\sum_{p} \sum_{j}\left(E_{p, j} * C O_{2} e q 2_{j}\right)+T_{\text {ship }}+\left[N e t G H G_{\text {land }}\right] \ldots
$$

where,

Indices

$\begin{array}{ll}\mathrm{i} & : \text { resource/material input } \\ \mathrm{j} & : \text { energy/fuel input } \\ \mathrm{p} & : \text { a process in the supply chain }\end{array}$

\section{Variables}

$\mathrm{CO}_{2-}$ eq $1_{\mathrm{i}} \quad$ : amount of $\mathrm{GHG}$ (in grams) per $\mathrm{kg}$ of $\mathrm{R}_{\mathrm{i}}$ $\mathrm{CO}_{2}$-eq2 $\quad:$ amount of GHG (in grams) per $\mathrm{kWh}$ of $\mathrm{E}_{\mathrm{j}}$

$\mathrm{R}_{\mathrm{p}, \mathrm{i}}$

$E_{p, j}$ : amount of resource $\mathrm{i}$ (in $\mathrm{kg}$ ) in a given process $\mathrm{p}$

$\mathrm{T}_{\text {ship }}$ : amount of energy input $(\mathrm{kWh})$ in a given process $\mathrm{p}$

: GHG due to shipment of crude oil/biodiesel from Middle East/Thailand to Singapore

$\mathrm{T}_{\text {ship }}$ is only considered for cases 1 and 4, where ocean and coastal tankers are used respectively. Any greenhouse gases from land transportation within the region are considered negligible. Direct land use change impacts [Net $\left.\mathrm{GHG}_{\text {land }}\right]$ is discussed in the next section. 


\subsection{Net GHG from direct land use change (LUC)}

Direct land use change or LUC is associated with the conversion of land area for the purpose of the supply chain production of a biofuel product [13]. Estimations of GHG emissions from direct LUC have been discussed in many reports [3, 9, 11]. But to date, there is no internationally recognized "standard model" or data relating to land use practices. Therefore, the authors emphasize that in this article, the 'best' and 'worst' case for LUC does no represent a globally accepted benchmark for GHG emissions for any agriculture-related land use applications.

The estimation of direct LUC applied for case studies 2 and 3 is the projected GHG emissions due to the clearing of a forestland area (deforestation) for growing palm oil biomass required per $1 \mathrm{MJ}$ biodiesel. For each case, the net GHG from palm oil LUC is calculated as:

$$
\mathrm{NetGHG}_{\text {land }}=\mathrm{LUC}_{\mathrm{CO} 2 \text {-eq }}-\mathrm{Palm}_{\mathrm{CO} 2}
$$

where

LUC $_{\mathrm{CO} 2 \text {-eq }}: \quad$ The total GHG emissions (per year) due to the clearance of tropical forest area to produce crude palm oil

Palm $\mathrm{CO2-eq} \mathrm{:} \mathrm{The} \mathrm{amount} \mathrm{of} \mathrm{CO}_{2}$ absorbed by the palm tree (also per year).

Chen [7] estimated that $0.87 \mathrm{~kg} \mathrm{CO}_{2}$ can be absorbed by palm oil plantations via photosynthesis per $\mathrm{kg}$ CPO produced. Since $0.026 \mathrm{~kg}$ biodiesel is equivalent to $1 \mathrm{MJ}$ biodiesel, the amount of $\mathrm{CPO}$ required in its production is $0.0273 \mathrm{~kg}$. This can be translated to $0.87 \times 0.0273=0.002375 \mathrm{~kg} \mathrm{CO}_{2}$-eq sequestered per MJ biodiesel. For 'best' reported case, palm oil is grown on existing cropland and hence: $\mathrm{LUC}_{\mathrm{CO} 2-\mathrm{eq}}=0$.

The focus for 'worst' case is on GHG emissions from deforestation. It has been projected that for every $\mathrm{kg}$ of $\mathrm{CPO}$ produced, about $6.65 \mathrm{~kg}$ of $\mathrm{CO}_{2}$-eq is released to the atmosphere due to carbon losses from direct LUC (deforestation) [9]. This corresponds to $\mathrm{CO}_{2}$ emissions of:

$\Rightarrow \quad 6.65 \times 0.0273=0.1815 \mathrm{~kg} \mathrm{CO}_{2}$-eq released for every MJ biodiesel.

NetGHG ${ }_{\text {land }}$ is considered zero for cases 1 and 4 .

\section{Results and discussions}

The results are displayed in figures 5 to 8 . It can be observed from fig. 5 that most of the GHG are first of all from crude oil extraction (68\% of the total) and next, the refinery (about 32\%). Very minimal emissions are observed from the delivery of crude oil to Singapore and even less from crude oil storage and handling.

Fig. 6 illustrates the environmental benefit of palm oil grown on dedicated cropland to produce biofuels (where $\mathrm{LUC}_{\mathrm{CO} 2 \text {-eq }}=0$ ). Any contributions to global warming from plantation, milling and the biorefinery can be considered insignificant compared to large benefits of sequestering $\mathrm{CO}_{2}$ by palm trees via 
photosynthesis. The total net GHG generated is negative for the entire biodiesel life cycle. For case 2 biodiesel can be regarded as an environmentally friendly and sustainable option for replacing conventional fuels.

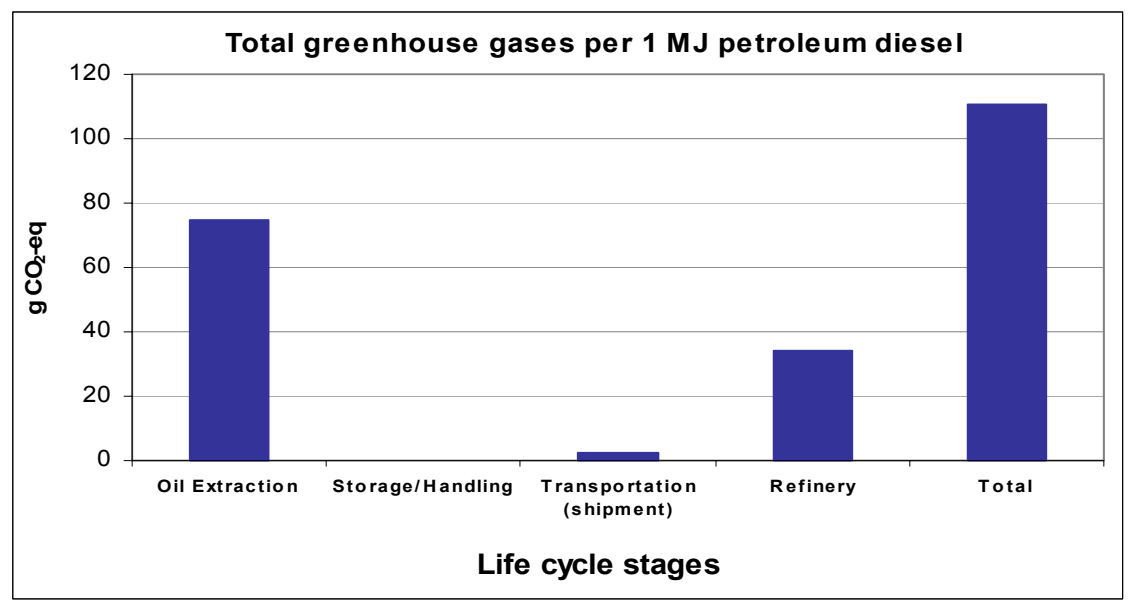

Figure 5: GHG results for the conventional production of $1 \mathrm{MJ}$ petro-diesel.

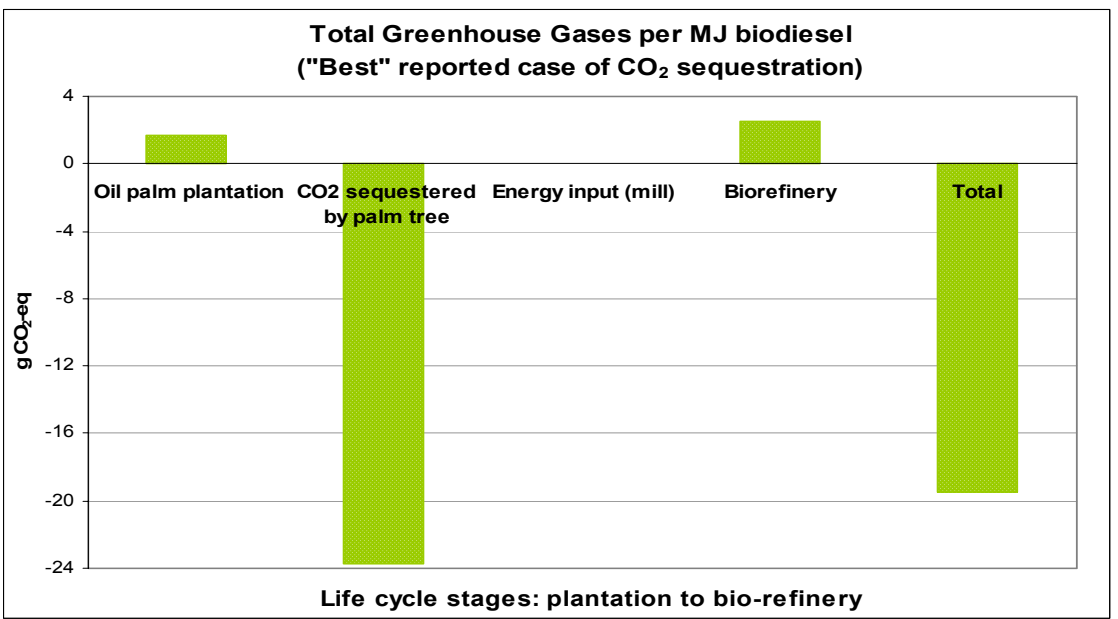

Figure 6: GHG results for $1 \mathrm{MJ}$ biodiesel from palm oil ('best' case of land use).

Fig. 7 displays one of the 'worst' case of land use change for growing palm oil to produce biodiesel [9]. The attempt to sequester $\mathrm{CO}_{2}$ from palm trees pales in comparison to the huge amounts of GHG emissions caused by deforestation. All other stage (plantation, milling, biorefinery) for palm oil to biodiesel is taken 


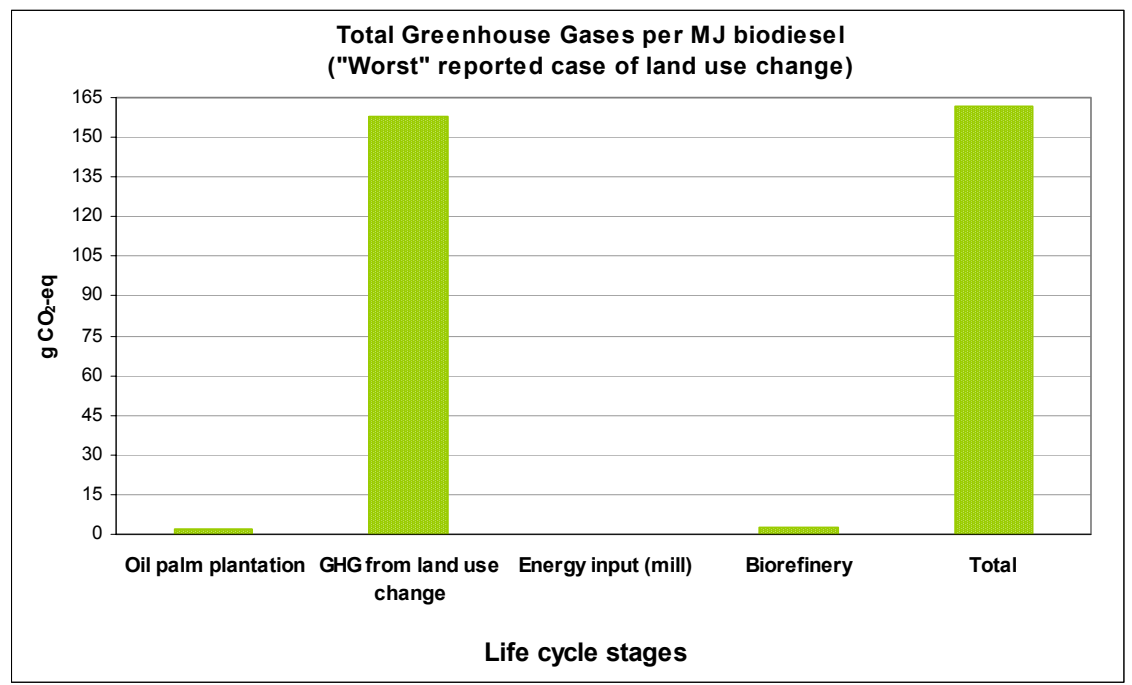

Figure 7: GHG results of $1 \mathrm{MJ}$ biodiesel from palm oil ('worst' case of LUC).

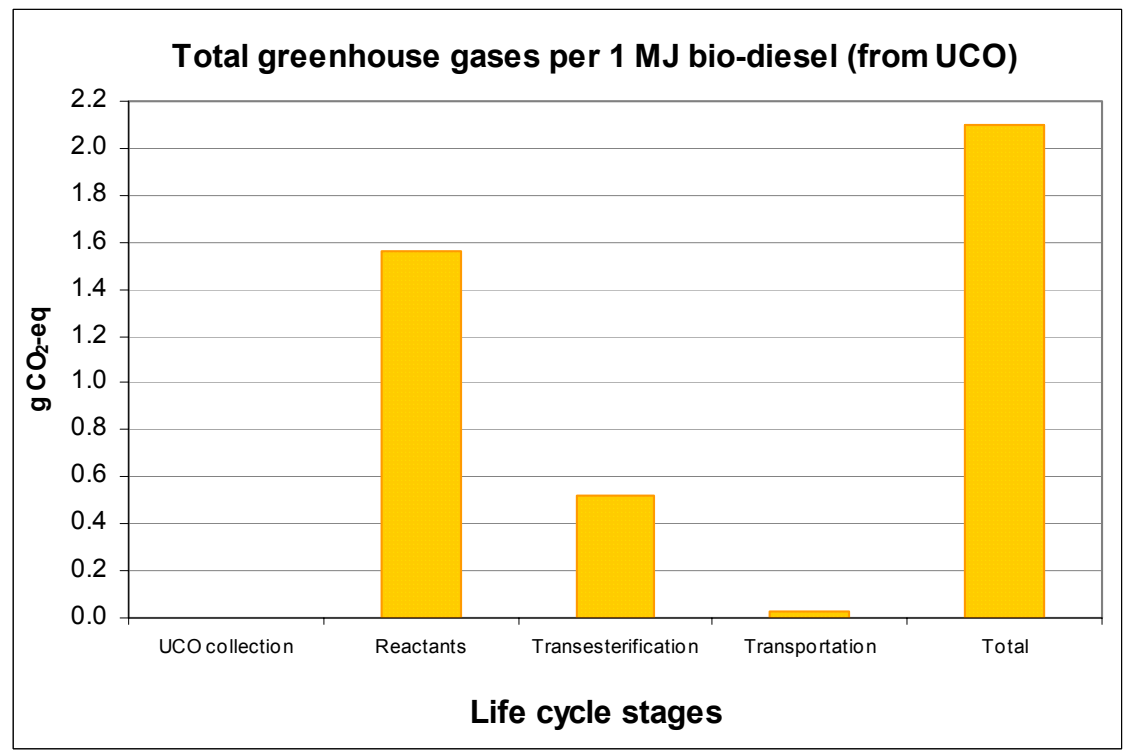

Figure 8: $\quad$ GHG results of $1 \mathrm{MJ}$ biodiesel from UCO.

to display the same trend as fig. 6 since the same practise for palm oil processing is considered.

Finally, fig. 8 displays the GHG for the life cycle stages of UCO to biodiesel produced in Thailand [12]. The greenhouse emissions are mostly from the use of 
reactants $(75 \%$ of the total) and the rest are from electrical energy inputs for the process. Very minimal emissions are shown to be from transportation.

A final comparison of all four cases is displayed in fig. 9. As expected, the least preferred option is case 3. The generation of GHGs from the conventional production of petro-diesel (case 1) is less than those from case 3. These two examples highlight that if not produced sustainably, biodiesel are worse than conventional fuels in their contribution to global warming.

The huge contrast between the environmental performances of cases 2 and 3 show that biofuels can potentially be a carbon negative source of energy, but their actual ability to offset GHGs depend on how the biomass feedstock is produced.

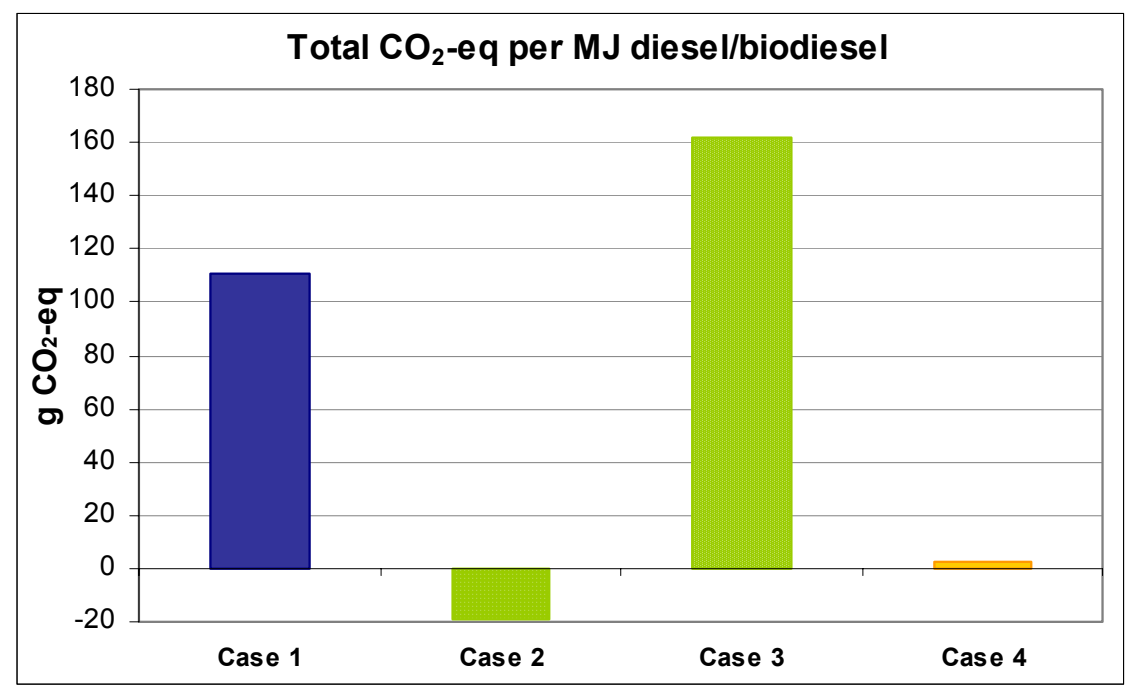

Figure 9: Comparison of total GHG for all 4 cases.

The fourth option, which is the conversion of UCO into biodiesel, exhibits great prospective for the recycling of used or waste oils, as well as, for reducing global warming impacts. Such sustainable biodiesel production strategies, from non-edible sources, are expected to result in improved air quality and greenhouse gas mitigation [13].

\subsection{Further discussions on direct LUC}

The sustainability of biofuel production systems is under intense scrutiny as their contribution towards, or ability to reduce, greenhouse gases remain unclear and controversial $[10,11]$. In this article, the authors attempt to demonstrate the two extreme ends of the global warming impacts of biodiesel based on 'best' and 'worst' reported cases of palm oil biomass resources, and compare their environmental performances with conventional fossil fuel and another source of biodiesel. 
Case studies 2 and 3 were based on the amounts of $\mathrm{CO}_{2}$ sequestration by palm trees [7], and the net GHGs arising from direct LUC [9]. It should be highlighted again that presently there are no global standards or models of assessing greenhouse gases from direct LUC [14]. The method of calculation presented in this article does not necessarily represent a global or "standard" measure of GHG emissions for any agriculture-related land practises. For example, Reijnders and Huijbregts [15] reported that GHGs from palm oil plantations which replace tropical forests can range between 2.8 to $19.7 \mathrm{~kg} \mathrm{CO}_{2}$-eq per $\mathrm{kg}$ palm oil. By applying these values in Eqn (2), the total global warming results for case 3 will decrease slightly (with $2.8 \mathrm{~kg} \mathrm{CO}_{2}$-eq per $\mathrm{kg}$ palm oil) or increase tremendously (19.7 kg CO 2 -eq per kg palm oil).

However, it is worth noting that generally many scientists unanimously agree that biofuels produced from converted land, particularly tropical rainforests, have greater GHG impacts than the fossil fuels they replace $[9,11,15]$.

\section{Conclusions}

Worldwide, the primary focus of air pollution mitigation is on greenhouse gas reduction or minimization. Biofuels are expected to help moderate global warming impacts as well as reduce the dependence on fossil fuels. However, caution should be employed in the move towards the large scale replacement of conventional energy resources with renewable ones. Although claimed to be "carbon neutral", the actual potential of any renewable fuel to absorb $\mathrm{CO}_{2}$ should be properly measured through its life cycle, or, from cradle-to-pump.

Tools to model or measure the carbon footprint of products are necessary to ensure that any strategies established for promoting renewable energy sources will properly mitigate - rather than contribute to - greenhouse gases in the atmosphere [16]. This kind of work demonstrates the importance of carbon footprint measurement tools, based on LCA, to provide relevant information necessary in establishing the right policies and strategies aimed at minimizing greenhouse gas pollution.

\section{References}

[1] Janulis, P., Reduction of energy consumption in biodiesel fuel life cycle, Renewable Energy, 29, pp. 861-871, 2004.

[2] Haverkort, A., Bindraban, P. \& Bos, H. (editors), Food, fuel or forest: Opportunities, threats and knowledge gaps of feedstock production for bio-energy, Proceedings: Wageningen, Netherlands, March 2, 2007.

[3] Koh, L.P. \& Wilcove, D.S., Oil palm: disinformation enables deforestation, Trends in Ecology \& Evolution, 24, pp. 67-68, 2009.

[4] Carbon Measurement Toolkit, Swedish Environmental Management Council, Stockholm, Sweden, 2009, Online. http://www.msr.se/en/Aboutus/Projects/carbon-footprint/

[5] Sheehan, J., Camobreco, V., Duffield, J., Graboski, M. \& Shapouri, H., Life cycle inventory of biodiesel and petroleum diesel for use in urban 
bus, Final Report, National Renewable Energy Laboratory (NREL), U.S. Department of Energy, 1998.

[6] Kim, S.S. \& Dale, S.B., Life cycle assessment of various cropping system utilized for producing biofuels: bioethanol and biodiesel, Biomass and Bioenergy, 29(6), pp. 426-439, 2005.

[7] Chen, S.S., LCA approach to illustrate palm oil's sustainability advantage, International Palm Oil Sustainability Conference, Sabah, Malaysia, April 13-15, 2008.

[8] Schmidt, J.H., Life cycle assessment of rapeseed oil and palm oil, $\mathrm{PhD}$ thesis, Department of Development and Planning, Aalborg University, Aalborg, Denmark, 2007.

[9] Wicke, B., Dornburg, V., Junginger, M. \& Faaij, A., Different palm oil production systems for energy purposes and their greenhouse gas implications, Biomass and Bioenergy, 32, pp. 1322-1337, 2008.

[10] Fitzherbert, E.B., Struebig, M.J., Morel, A., Danielsen, F., Bruhl, C.A., Donald, P.F. \& Phalan, B., How will oil palm expansion affect biodiversity?, Trends in Ecology \& Evolution, 23 (10), pp. 538-545, Oct 2008.

[11] Fargione, J., Hill, J., Tilman, D., Polasky, S. \& Hawthorne, P., Land clearing and the biofuel carbon debt, Science, 319(5867), pp. 1235-1238, 2008.

[12] Pleanjai, A., Gheewala, S.H. \& Garivait, S. Greenhouse gas emissions from production and use of used cooking oil methyl ester as transport fuel in Thailand, Journal of Cleaner Production, 2009. In print

[13] Demirbas, A. Biodiesel from waste cooking oil via base-catalytic and supercritical methanol transesterification, Energy Conversion and Management, 50(4), pp. 923-927, 2009.

[14] Kim, H., Kim, S. \& Dale, B.E., Biofuels, Land Use Change, and Greenhouse Gas Emissions: Some Unexplored Variables, Environmental Science and Technology, 43(3), pp. 961-967, 2009.

[15] Reijnders, L. \& Huijbregts, M.A.J., Palm oil and the emissions of carbonbased greenhouse gases, Journal of Cleaner Production, 16(4), pp. 477482, 2008.

[16] von Blottnitz, H. \& Curran, M.A., A review of assessments conducted on bio-ethanol as a transportation fuel from a net energy, greenhouse gas, and environmental life cycle perspective, Journal of Cleaner Production, 15(7), pp. 607-619, 2007. 